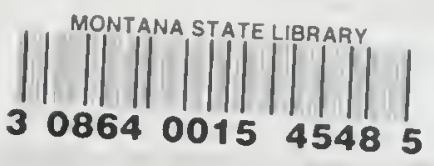

\title{
BIOLOGICAL INTEGRITY OF
}

MILL CREEK, PINE CREEK, AND TOM MINER CREEK BASED ON THE COMPOSITION AND STRUCTURE OF THE BENTHIC ALGAE COMMUNITY

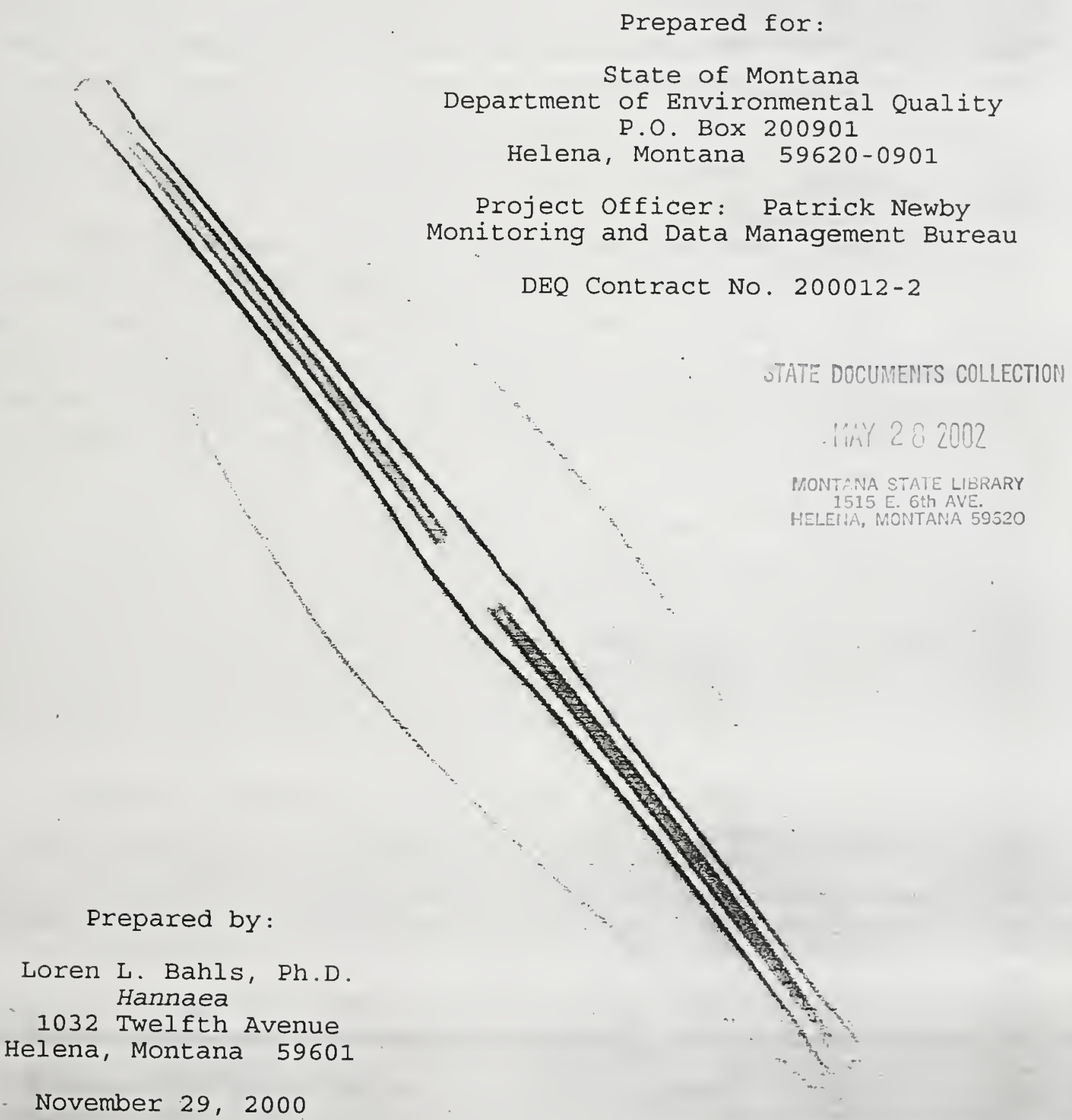

Prlated on 100 r Recyoled Post-Consumer Paper 
-

-

- 


\section{SUMOMARY}

In July and August 2000, composite periphyton samples were collected from Mill Creek, Pine Creek, and Tom Miner Creek in the Paradise Valley south of Livingston for the purpose of assessing whether these streams are water-quality limited and in need of TMDLs. The samples were collected following DEQ standard operating procedures, processed and analyzed using standard methods for periphyton, and evaluated following modified USEPA rapid bioassessment protocols for wadeable streams.

Mill Creek had a normal algal assemblage that indicated slight nutrient enrichment. Diatom association metrics at the Mill Creek site indicated minor impairment but full support of aquatic life uses (Table 5). 'Slightly elevated percent dominant species and siltation indexes and a few abnormal diatom cells resulted in an overall rating of "good" biological integrity.

The algal flora in Pine Creek was sparse, both in terms of cell numbers and taxa richness. The dominant algal species here indicated very cold and very fast flowing waters, and very small concentrations of nutrients. The moderate stress indicated by the algal assemblage here was probably the consequence of naturally austere habitat conditions.

The algal assemblages at both sites in Tom Miner Creek indicated moderate impairment and partial support of aquatic life uses. The leading cause of this impairment was siltation. Both sites also had somewhat depressed pollution indexes, indicating minor organic enrichment. A few abnormal diatom cells were also found at each site. The two sites on Tom Miner Creek had nearly $80 \%$ of their diatom assemblages in common, indicating that they were virtually identical in their chemical, physical, and biological characteristics. 
-

-

- 


\section{INTRODUCTION}

This report evaluates the biological integrity, support of aquatic life uses, and probable causes of impairment to those uses in Mill Creek, Pine Creek, and Tom Miner Creek, which are tributaries of the upper Yellowstone River between Livingston and Gardiner, Montana. The purpose of this report is to provide information that will help the state of Montana determine whether these streams are water-quality limited and in need of TMDLs.

The federal Clean water Act directs states to develop water pollution control plans (Total Maximum Daily Loads or TMDLs) that set limits on pollution loading to water-quality limited waters. Water-quality limited waters are lakes and stream segments that do not meet water-quality standards, that is, that do not fully support their beneficial uses. The Clean water Act and USEPA regulations require each state to (1) identify waters that are water-quality limited, (2) prioritize and target waters for TMDLs, and (3) develop TMDL plans to attain and maintain water-. quality standards for all water-quality limited waters.

Evaluation of use support in this report is based on the species composition and structure of the periphyton (benthic algae, phytobenthos) community at four sites that were sampled in July and August 2000. The periphyton community is a basic biological component of all aquatic ecosystems. Periphyton accounts for much of the primary production and biological diversity in Montana streams (Bahls et al. 1992).

Plafkin et al. (1989) and Stevenson and Bahls (1999) list several advantages of using periphyton in biological assessments:

- Algae are universally present in large numbers in all streams and unimpaired periphyton assemblages typically support a large number $(>30)$ of species; 
-

-

잉 
Algae have rapid reproduction rates and short life cycles, making them useful indicators of short-term impacts;

As primary producers, algae are most directly affected by physical and chemical factors, such as temperature, nutrients, dissolved salts, and toxins;

Sampling is quick, easy and inexpensive, and causes minimal damage to resident biota and their habitat;

Standard methods and criteria exist for evaluating the composition, structure, and biomass of algal associations;

Identification to species is straightforward for the diatoms, for which there is a large body of taxonomic and ecological literature;

- Excessive algae 9iowth in streams is often correctly perceived as a problem by the public.

Periphyton and other biological communities reflect the biological integrity $y^{1}$ of waterbodies; restoring and maintaining the biological integrity of waterbodies is a goal of the federal Clean Water Act;

Periphyton and other biological communities integrate the effects of different stressors and provide a measure of their aggregate impact; and

Periphyton and other biological communities may be the only practical means of evaluating impacts from non-point sources of pollution where specific ambient criteria do not exist (e.g., impacts that degrade habitat or increase nutrients).

Periphyton is a diverse assortment of simple photosynthetic organisms called algae, and other microorganisms that live attached to or in close proximity of the stream bottom. Most algae, such as the diatoms, are microscopic. Diatoms are distinguished by having a cell wall composed of opaline glass-hydrated amorphous silica. Diatoms often carpet a stream bottom

1 Biological integrity is defined as "the ability of an aquatic ecosystem to support and maintain a balanced, integrated, adaptive community of organisms having a species composition, diversity, and functional organization comparable to that of natural habitats within a region" (Karr and Dudley 1981). 
-

0 
with a slippery brown film.

Some algae, such as the filamentous greens, are conspicuous and theix excessive growth may be aesthetically displeasing, deplete dissolved oxygen, interfere with fishing and fish spawning, clog water filters and irrigation intakes, create tastes and odors in drinking water, and cause other problems.

\section{PROJECT AREA AND SAMPLING SITES}

The project area is located in southern Park County in southcentral Montana. Mill Creek and Pine Creek are east side tributaries of the Yellowstone River that drain the Absaroka Mountain Range (maximum elevation 11,206 feet) south of Livingston. Pine Creek is a short (ca. $8 \mathrm{mi}$.), high gradient second-order stream that begins at Pine Creek Lake in the Absaroka-Beartooth Wilderness Area. Much of the upper watershed is unroaded. Mill Creek is a longer (ca. $22 \mathrm{mi}$ ), third-order stream with a road running along most of its length.

Tom Miner Creek enters the Yellowstone River from the west about 16 miles north of Gardiner, Montana. The headwaters of Tom Miner Creek are in the Gallatin Range (max. elevation 10,992 feet) just north of Yellowstone National Park. Tom Miner Creek. is a third order stream about 15 miles long with a road running parallel to the stream along most of its length.

All three creeks head in the Middle Rockies Ecoregion of North America; the very lowest reaches of these streams pass through the Montana Valley and Foothill Prairies Ecoregion (Woods et al. 1999). The surface geology of the watersheds consists mainly of volcanic rocks of Tertiary age and undifferentiated metamorphic rocks of Precambrian age (Renfro and Feray 1972). Vegetation is alpine tundra at the highest elevations, mixed 
-

-

- 
conifer forest at intermediate elevations, and mixed grassland at lower elevations (USDA 1976).

Periphyton samples were collected at one site each on Mill Creek and Pine Creek in late July 2000 (Map 1, Table 1). Both sites are located at an elevation of about 5,500 feet. Samples were collected at two sites on Tom Miner Creek in mid August 2000 (Map 2, Table 1). The elevation of both sampling sites on Tom Miner Creek is about 5,000 feet.

Mill Creek, Pine Creek, and Tom. Miner Creek are all classified B-1 in the Montana Surface Water Quality Standards.

\section{METHODS}

Periphyton samples were collected by Patrick Newby of the MDEQ Monitoring and Data Management Bureau following standard operating procedures of the MDEQ Planning, Prevention, and Assistance Division.

Using appropriate tools, microalgae were scraped, brushed, or sucked from natural substrates in proportion to the rank of those substrates at the study site. Macroalgae were picked by hand in proportion to their abundance at the site. All collections of microalgae and macroalgae were pooled into a common container and preserved with Lugol's solution.

The samples were examined to estimate the relative abundance and rank by biovolume of diatoms and genera of soft (non-diatom) algae according to the method described in Bahls (1993). Soft algae were identified using Dillard (1999), Prescott (1978), Smith (1950), and Whitford and Schumacher (1984). These books also served as references on the ecology of the soft algae, along with Palmer (1977). 
둥

당

0 
After the identification of soft algae, the raw periphyton samples were cleaned of organic matter using sulfuric acid, and permanent diatom slides were prepared using Naphrax, a high refractive index mounting medium, following Standard Methods for the Examination of Water and Wastewater (APHA 1998). Between 400 and 423 diatom cells (800 to 846 valves) were counted at random and identified to species. The following were used as the main taxonomic and autecological references for the diatoms: Krammer and Lange-Bertalot 1986, 1988, 1991a, 1991b; Patrick and Reimer 1966, 1975. Lowe (1974) was also used as an ecological reference for the diatoms.

The diatom proportional counts were used to generate an array of diatom association metrics (Table 2). A metric is a characteristic of the biota that changes in some predictable way with increased human influence (Barbour et al. 1999).

Metric values from Mill Creek, Pine Creek, and Tom Miner Creek were compared to numeric biocriteria or threshold values developed for streams in the Rocky Mountain Ecoregions of Montana (Table 3). These criteria are based on metric values measured in least-impaired reference streams (Bahls et al. 1992) and on metric values measured in streams that are known to be impaired by various sources and causes of pollution (Bahls 1993).

The criteria in Table 3 distinguish among four levels of impairment and three levels of aquatic life use support: no impairment or only minor impairment (full support); moderate impairment (partial support); and severe impairment (nonsupport). These impairment levels correspond to excellent, good, fair, and poor biological integrity, respectively.

Quality Assurance. Several steps were taken to assure that the study results are accurate and reproducible. 
0

-

○ 
Upon receipt of the samples, station and sample information were recorded in a laboratory notebook and the samples were assigned a unique number compatible with the Montana Diatom Database, e.g., 1994-01. The first part of this number (1994) designates the sampling site (Pine Creek Station 1); the second part of this number (01) designates the number of periphyton samples that have been collected at this site to date for which data have been entered into the Montana Diatom Database.

Sample observations and analyses of soft (non-diatom) algae were recorded in a lab notebook along with station and sample information provided by MDEQ. A portion of the raw sample was used to make duplicate diatom slides. After completing the diatom proportional count, the slide used for the count will be deposited in the University of Montana Herbarium in Missoula. The other slide will be retained by Hannaea in Helena.

On completion of the project, station information, sample information, and diatom proportional count data will be entered into the Montana Diatom Database.

\section{RESULTS AND DISCUSSION}

Results are presented in Tables 4 and 5 , which are located near the end of this report following the Literature cited section. Spreadsheets containing completed diatom proportional counts, with species' pollution tolerance classes (PTC) and percent abundances, are attached as Appendix A.

\section{SAMPLE NOTES}

- Mill Creek station 1. In addition to vegetative cells, many zoospores of Ulothrix were alsn present. 
Pine Creek station 1 . This sample was very sparse. The most abundant diatoms were species of Gomphonema.

Tom Miner Creek station 1. The Cladophora in this sample was sparsely branched and resembled Rhizoclonium.

Tom Miner Creek Station 2. Mosses dominated this sample. The Cladophora in this sample was sparsely branched and resembled Rhizoclonium.

\section{NON-DIATOM ALGAE}

The periphyton sample from Mill creek was dominated by Ulothrix zonata, a filamentous green alga, and by diatoms; cyanobacteria were rare (Table 4). Ulothrix zonata is commonly found in cold, rapidly flowing streams that are somewhat enriched with nutrients.

The sample from Pine Creek contained chrysophytes and cyanobacteria, but no green algae (Table 4). Only two genera of non-diatom algae were observed. Algal assemblages with few taxa and a small number of cells are typical of very cold mountain streams with steep gradients and low nutrient concentrations. Hydrurus foetidus, a cold-water chrysophyte, ranked first in biovolume and diatoms ranked second; cyanobacteria (Phormidium sp.) ranked third at this station.

Samples from both sites on Tom Miner Creek contained a mix of green algae, diatoms, and cyanobacteria (Table 4). Diatoms were the most abundant algae at both sites, followed by the green filamentous alga Cladophora. In addition, both sites contained the red alga Audouinella. Euglena, an indicator of organic enrichment, was rare at the upstream site (station 1). The algal assemblages in Tom Miner Creek indicate a moderate level of 
-

수 
enrichment.

\section{DIATOMS}

Diatom association metrics at the Mill Creek site indicated minor impairment but full support of aquatic life uses (Table 5). Slightly elevated percent dominant species and siltation indexes and a few abnormal diatom cells resulted in an overall rating of "good" biological integrity.

The diatom association in Mill Creek was dominated by Hannaea arcus (Table 5). This species is common in mountain streams and large cold lakes in northern latitudes. It tolerates some nutrient enrichment but is sensitive to pollution from sewage. Because of the elevated numbers of Hannaea arcus here, the percent dominant species index sightly exceeded the threshold for minor impairment. Since this species may be found in large numbers in relatively pristine waters, its dominance in Mill Creek may not be due to cultural enrichment.

The sample from Pine Creek was dominated by Gomphonema olivaceoides (Table 5). This is a cosmopolitan cold water species that often dominates the diatom assemblages of mountain streams. In Montana, it is particularly abundant in streams draining the Absaroka and Beartooth Mountains (unpublished data). Its dominance in Pine Creek, along with a small number of diatom taxa and a low diversity index, probably indicates natural stress due to cold water, fast currents, and low nutrients.

The siltation index at both sites on Tom Miner Creek indicated moderate impairment. and only partial support of aquatic life uses (Table 5). Both sites supported a large number of diatoms in the genera Navicula and Nitzschia. These are motile diatoms that are adapted to living on aggrading substrates. 
-

-

- 
Both sites on Tom Miner Creek had somewhat depressed pollution indexes (Table 5), indicating minor organic enrichment. A few abnormal diatom cells were also found at each site. The two sites on Tom Miner Creek had nearly 80\% of their diatom assemblages in common, indicating that they were very similar chemically, physically, and biologically.

\section{LITERATURE CITED}

APHA. 1998. Standard Methods for the Examination of Water and Wastewater. 20th Edition. American Public Health Association, Washington, D.C.

Bahls, L.L. 1979. Benthic diatom diversity as a measure of water quality. Proc. Mont. Acad. Sci. 38:1-6.

Bahls, L.L. 1993. Periphyton Bioassessment Methods for Montana Streams (Revised). Montana Department of Health and Environmental Sciences, Helena.

Bahls, L.L., Bob Bukantis, and Steve Tralles. 1992. Benchmark Biology of Montana Reference Streams. Montana Department of Health and Environmental Sciences, Helena.

Barbour, M.T., J. Gerritsen, B.D. Snyder, and J.B. Stribling. 1999. Rapid Bioassessment Protocols for Use in Streams and Wadeable Rivers: Periphyton, Benthic Macroinvertebrates and Fish. Second Edition. EPA/841-B-99-002. U.S. EPA, Office of Water, Washington, D.C.

Dillard, G.E. 1999. Common Freshwater Algae of the United States. J. Cramer, Berlin.

Johansen, J.R. 1999. Diatoms of Aerial Habitats. Chapter 12 in Stoermer, E.F., and J.P. Smol (eds.), The Diatoms, Cambridge University Press, New York.

Karr, J.R., and D.R. Dudley. 1981. Ecological perspectives on water quality goals. Environmental Management 5:55-69.

Krammer, K., and H. Lange-Bertalot. 1986. Bacillariophyceae, Part 2, Volume 1: Naviculaceae. In EttI, H., J. Gerloff, H. Heynig, and D. Mollenhauer (eds.), Freshwater Flora of Middle Europe. Gustav Fischer Publisher, New York. 
6

0 
Krammer, K., and H. Lange-Bertalot. 1988. Bacillariophyceae, Part 2, Volume 2: Bacillariaceae, Epithemiaceae, Surirellaceae. In Ettl, H., J. Gerloff, H. Heynig, and D. Mollenhauer (eds.), Freshwater Flora of Middle Europe. Gustav Fischer Publisher, New York.

Krammer, K., and H. Lange-Bertalot. 1991a. Bacillariophyceae, Part 2, Volume 3: Centrales, Fragilariaceae, Eunotiaceae. In Ettl, H., J. Gerloff, H. Heynig, and D. Mollenhauer (eds.), Freshwater Flora of Middle Europe. Gustav Fischer Publisher, stuttgart.

Krammer, K., and H. Lange-Bertalot. 1991b. Bacillariophyceae, Part 2, Volume 4: Achnanthaceae, Critical Supplement to Navicula (Lineolatae) and Gomphonema, Complete List of Literature for Volumes 1-4. In Ettl, H., G. Gartner, J. Gerloff, H. Heynig, and D. Mollenhauer (eds.), Freshwater Flora of Middle Europe. Gustav Fischer Publisher, stuttgart.

Lange-Bertalot, Horst. 1979. Pollution tolerance of diatoms as a criterion for water quality estimation. Nova Hedwigia $64: 285-304$.

Lowe, R.L. 1974. Environmental Requirements and Pollution Tolerance of Freshwater Diatoms. EPA-670/4-74-005.

MCFarland, B.H., B.H. Hill, and W.T. Willingham. 1997. Abnormal Fragilaria spp. (Bacillariophyceae) in streams impacted by mine drainage. Jour. of Freshwater Ecology 12(1):141-149.

Palmer, C.M. 1977. Algae and Water Pollution: An Illustrated Manual on the Identification, Significance, and Control of Algae in water Supplies and in Polluted water. EPA-600/9-77-036.

Patrick, Ruth, and C.W. Reimer. 1966. The Diatoms of The United States Exclusive of Alaska and Hawaii. Volume 1: Fragilariaceae, Eunotiaceae, Achnanthaceae, Naviculaceae. Monograph Number 13, The Academy of Natural Sciences, Philadelphia.

Patrick, Ruth, and C.W. Reimer. 1975. The Diatoms of The United States Exclusive of Alaska and Hawaii. Volume 2, Part 1: Entomoneidaceae, Cymbellaceae, Gomphonemaceae, Epithemiaceae. Nonograph Number 13, The Academy of Natural Sciences, Philadelphia.

Plafkin, J.L., M.T. Barbour, K.D. Porter, S.K. Gross, and R.M. Hughes. 1989. Rapid Bioassessment Protocols for Use in Rivers and Streams: Benthic Macroinvertebrates and Fish. EPA 440-4-89-001. 
6




Prescott, G.W. 1978. How to know the Freshwater Algae. Third Edition. Wm. C. Brown Company Publishers, Dubuque, Iowa.

Renfro, H.B., and D.E. Feray. 1972. Geological Highway Map of the Northern Rocky Mountain Region. American Association of Petroleum Geologists, Tulsa, Oklahoma.

Smith, G.M. 1950. the Fresh-Water Algae of The United States. McGraw-Hill Book Company, New York.

Stevenson, R.J., and L.L. Bahls. 1999. Periphyton Protocols. Chapter 6 in Barbour, M.T., J. Gerritsen, B.D. Snyder, and J.B. Stribling. Rapid Bioassessment Protocols for Use in Streams and wadeable Rivers: Periphyton, Benthic Macroinvertebrates and Fish. Second Edition. EPA/841-B-99002. U.S. EPA, Office of Water, Washington, D.C.

USEA. 1976. Climax Vegetation of Montana (map). U. S. Department of Agriculture, Soil Conservation Service, Cartographic Unit, Portland.

Whitford, L.A., and G.J. Schumacher. 1984. A Manual of FreshWater Algae (Revised). Sparks Press, Raleigh, North Carolina.

Whittaker, R.H. 1952. A study of summer foliage insect communities in the Great Smoky Mountains. Ecological Monographs $22: 1-44$.

Woods, A.J., Omernik, J.M., Nesser, J.A., Shelden, J., and Azevedo, S.H. 1999. Ecoregions of Montana (color poster with map), U.S. Geological Survey, Reston, Virginia. 
6

c 



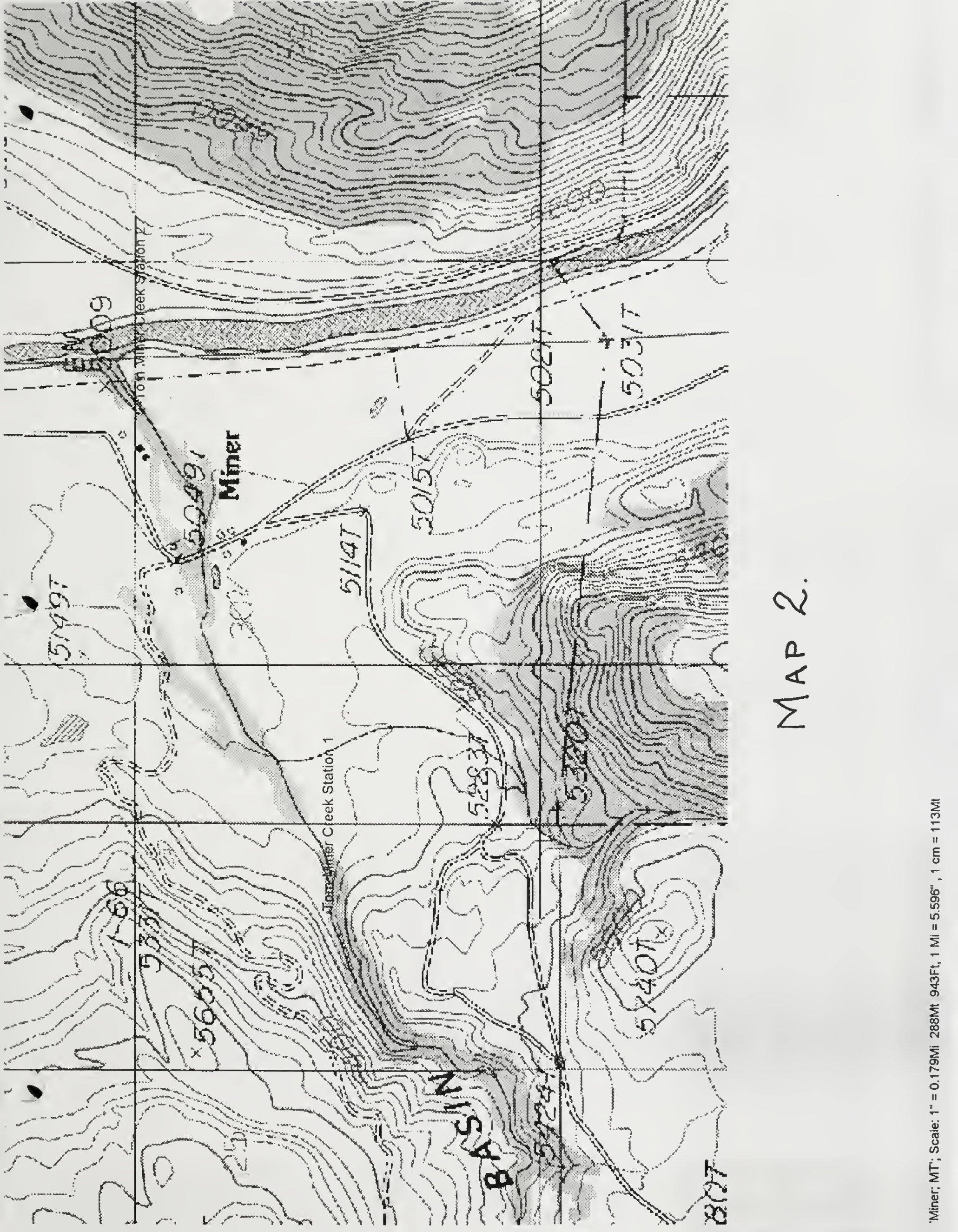


0

6

( 
Table 1. Location of periphyton stations on Mill Creek, Pine Creek, and Tom Miner Creek: Station codes, sample numbers in the Montana Diatom Database, latitudes and longitudes, and sample dates. Stations are listed in order from upstream to downstream.

\begin{tabular}{|c|c|c|c|c|}
\hline Location & $\begin{array}{l}\text { Station } \\
\text { Code }\end{array}$ & $\begin{array}{l}\text { Sample } \\
\text { Number }\end{array}$ & $\begin{array}{l}\text { Latitude/ } \\
\text { Longitude }\end{array}$ & $\begin{array}{l}\text { Sample } \\
\text { Date }\end{array}$ \\
\hline $\begin{array}{l}\text { Tom Miner Creek } \\
\text { at canyon mouth }\end{array}$ & Station 1 & 1996-01 & $\begin{array}{rrr}45 & 11 & 46 \\
110 & 55 & 07\end{array}$ & $08 / 17 / 00$ \\
\hline $\begin{array}{l}\text { Tom Miner Creek } \\
\text { at mouth }\end{array}$ & Station 2 & $1997-01$ & $\begin{array}{rrr}45 & 12 & 01 \\
110 & 54 & 09\end{array}$ & $08 / 17 / 00$ \\
\hline Mill Creek & Station 1 & $1995-01$ & $\begin{array}{rrr}45 & 20 & 10 \\
110 & 35 & 13\end{array}$ & $07 / 20 / 00$ \\
\hline Pine Creek & Station 1 & $1994-01$ & $\begin{array}{rrr}45 & 30 & 01 \\
110 & 31 & 46\end{array}$ & $07 / 27 / 00$ \\
\hline
\end{tabular}


(6)

6

1 


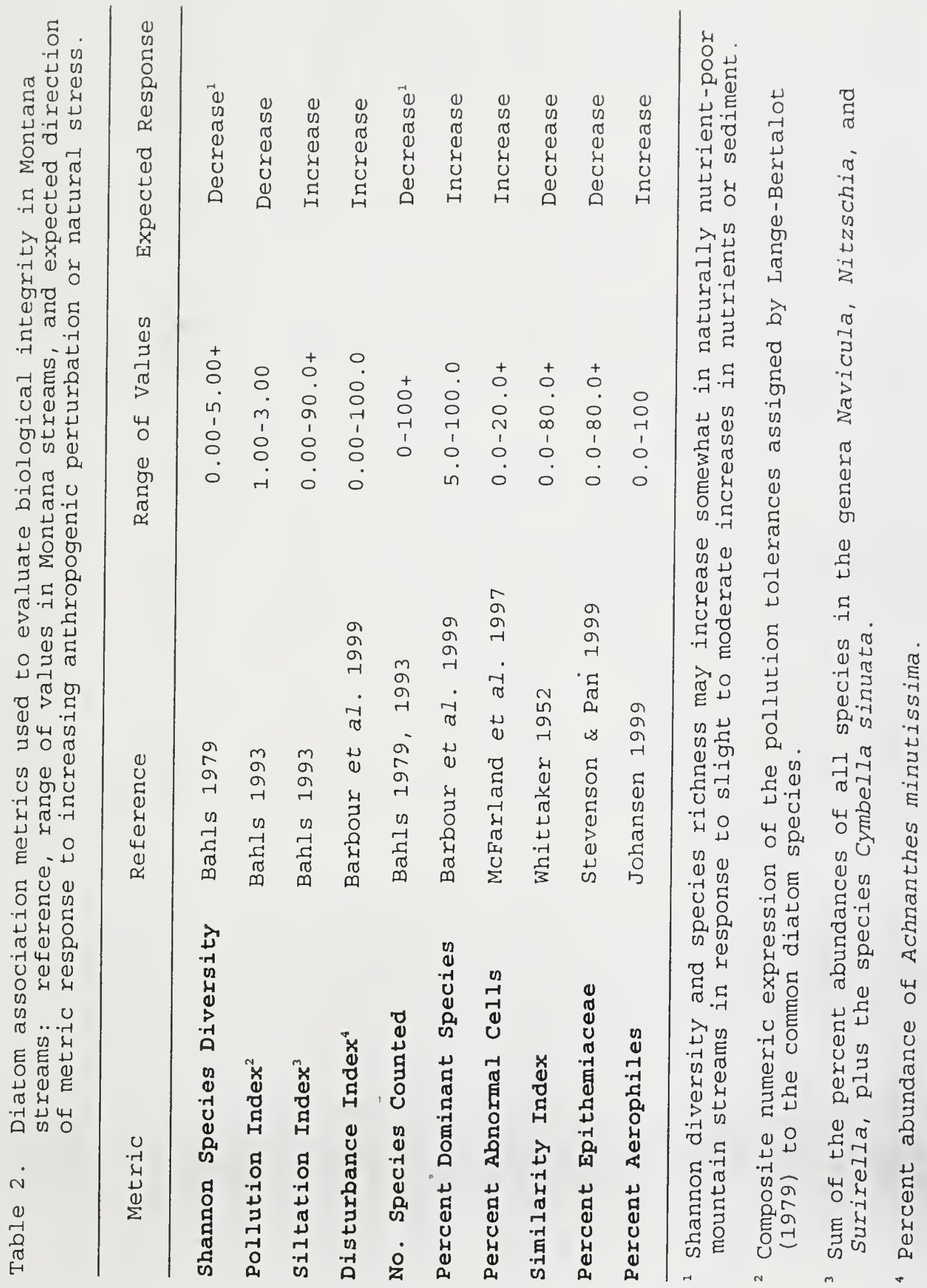




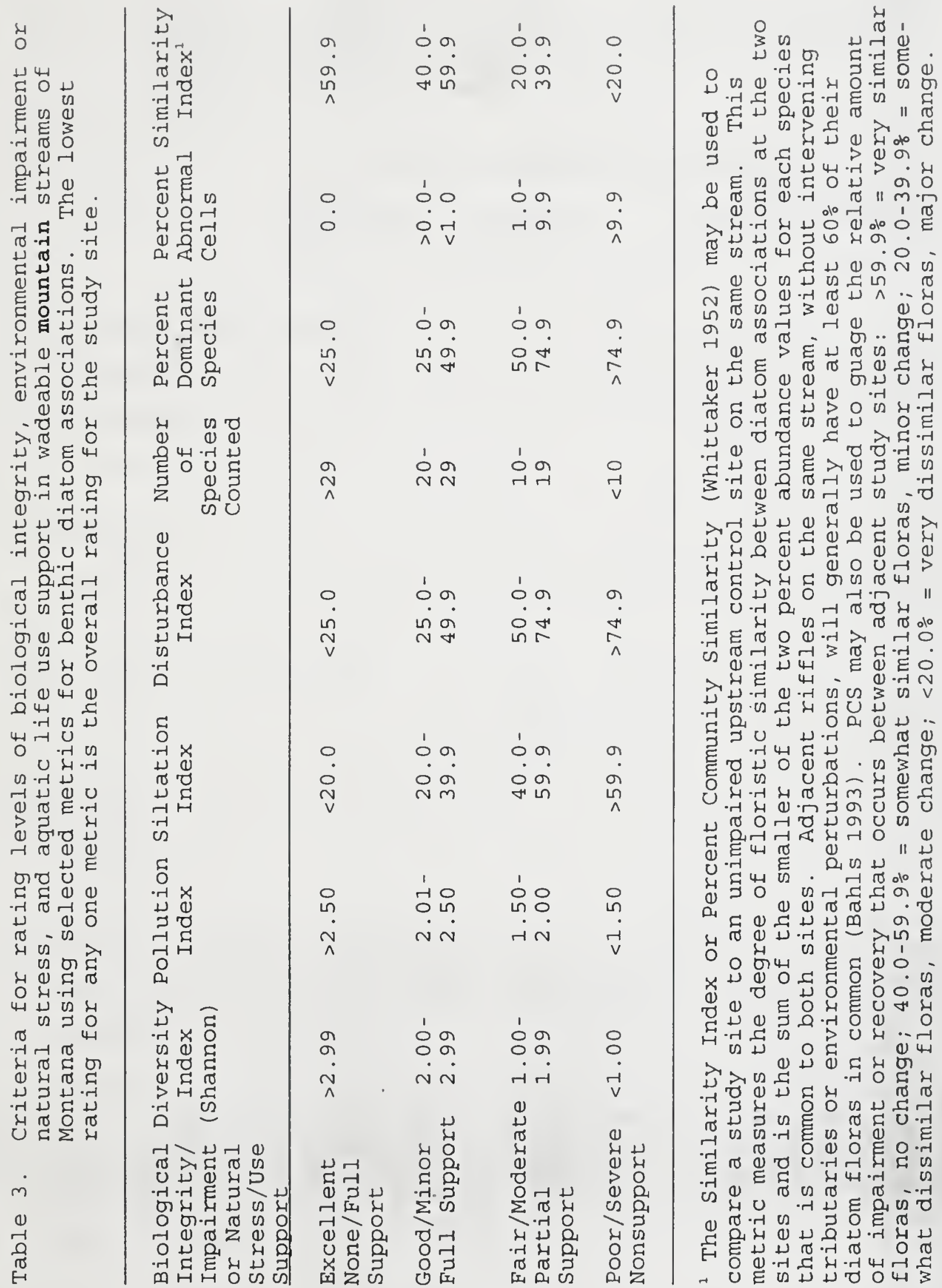


Table 4. Relative abundance of cells and rank by biovolume of diatoms and genera of non-diatom algae in periphyton samples collected from Mill Creek, Pine Creek, and Tom Miner Creek in the summer of 2000.

Relative Abundance ${ }^{1}$ and (Rank)

Taxa Mill Creek pine Creek

Tom Miner Creek

Station 1 Station $1 \quad$ Station 1 Station 2

Chlorophyta (green algae)

Cladophora

f (2)

a (2)

Closterium

○ (6)

c (3)

Ulothrix

d (1)

f (3)

○ (5)

\section{Euglenophyta}

Euglena

$r(7)$

Chrysophyta (golden algae)

Diatoms

a (2)

○ (2)

a (1)

a (1)

Hydrurus

C (1)

\section{Rhodophyta}

Auduuinella

c (5)

C (4)

Cyanophyta (cyanobacteria) ${ }^{2}$
Amphithrix
$r(3)$
Anabaena
$r$ (4)

○(6)

Phormidium

○ (3)

f (4)

$1 \mathrm{~d}=$ dominant $; \mathrm{a}=$ abundant $\mathrm{f}=$ frequent $; \mathrm{c}=$ common; $\mathrm{o}=$ occasional; $r=$ rare

2 Formerly known as blue-green algae. 
Table 5. Percent abundance of major diatom species ${ }^{1}$ and values of selected diatom association metrics for periphyton samples collected from Mill Creek, Pine Creek, and Tom Miner Creek in the summer of 2000.

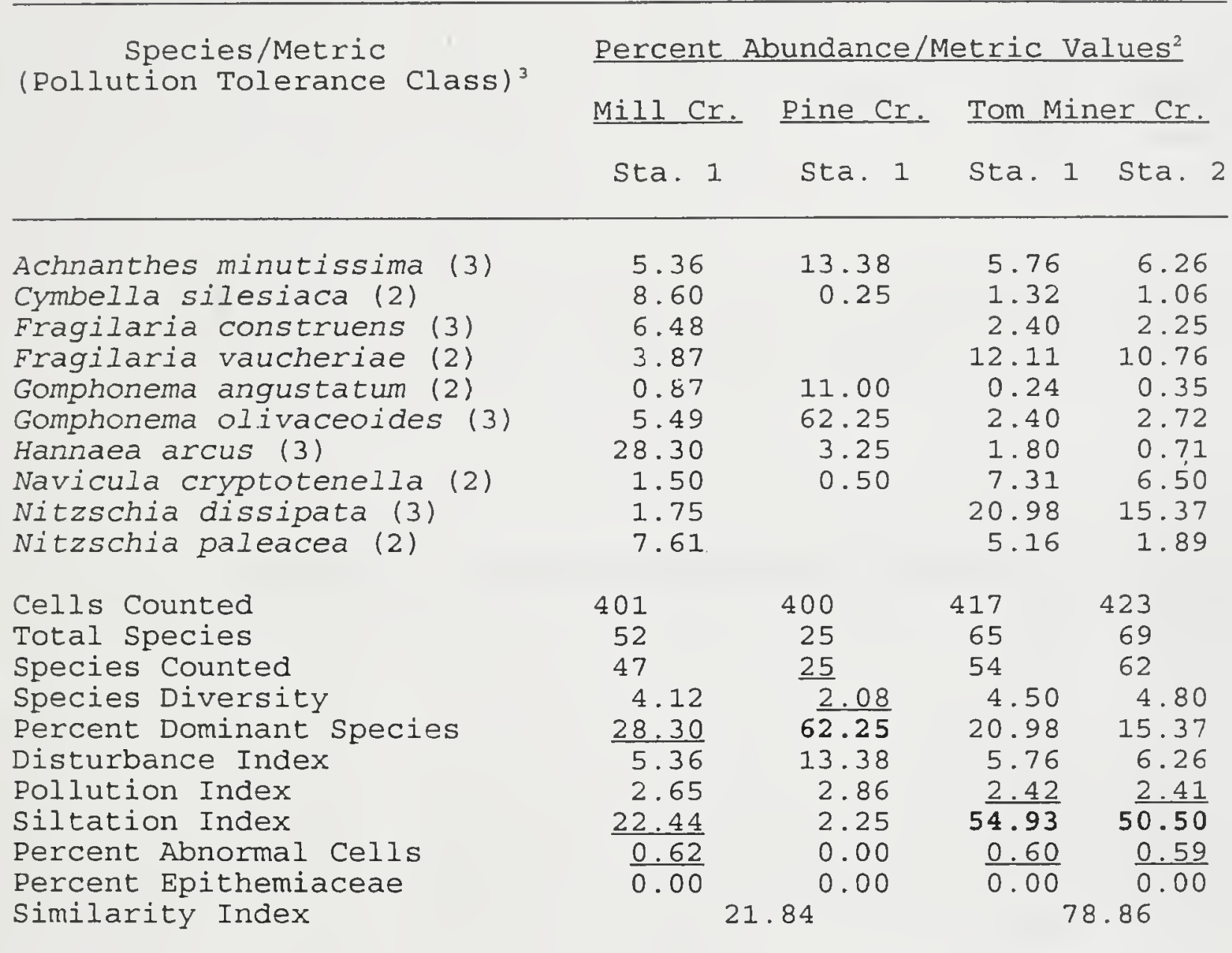

1 A major diatom species is here considered to be one that accounts for 5\% or more of the cells in one or more samples of a sample set.

2 Underlined values indicate good biological integrity, minor impairment, and full support of aquatic life uses; bold values indicate fair biological integrity, moderate impairment, and partial support of aquatic life uses; all other values indicate excellent biological integrity, no impairment, and full support of aquatic life uses when compared to criteria for mountain streams in Table 3 .

33 = sensitive to pollution; 2 = tolerant of pollution; 1 = most tolerant of pollution. 
APPENDIX A: DIATOM PROPORTIONAL COUNTS 


\begin{tabular}{|c|c|c|c|}
\hline Genus/Species Nariety & Pollution Tolerance Class & Count & Percent \\
\hline 199501 Achnanthes lanceolata & 2 & 29 & 3.62 \\
\hline 199501 Achnanthes minutissima & 3. & 43. & 5.36 \\
\hline 199501 Amphora pediculus & 3 & 3 & 0.37 \\
\hline 199501 Cocconeis placentula & 3 & 18 & 2.24 \\
\hline 199501 Cymbella cymbiformis & 3. & 1. & 0.12 \\
\hline 199501 Cymbella minuta & 2 & 2 & 0.25 \\
\hline 199501 Cymbella silesiaca & 2 & 69 & 8.60 \\
\hline 199501 Diatoma anceps & 3 & 1 & 0.12 \\
\hline 199501, Diatoma hiemale & 3 & 2. & 0.25 \\
\hline 199501 Diatoma mesodon & 3 & 8. & 1.00 \\
\hline 199501 Diatoma vulgaris & 3. & 0. & 0.00 \\
\hline 199501 Fragilaria brevistriata & 3. & 7 & 0.87 \\
\hline 199501 Fragilaria construens & 3 & 52 & 6.48 \\
\hline 199501 Fragilaria leptostauron & 3. & 11 & 1.37 \\
\hline 199501 Fragilaria pinnata & 3. & 9 & 1.12 \\
\hline 199501 Fragilaria vaucheriae & 2 & 31 & 3.87 \\
\hline 199501 Gomphoneis minuta & 3. & 1. & 0.12 \\
\hline 199501 Gomphonema angustatum & 2 & 7 & 0.87 \\
\hline 199501 Gomphonema clevei & 3 & 1. & 0.12 \\
\hline 199501 Gomphonema kobayasii & 3. & 14. & 1.75 \\
\hline 199501 Gomphonema minutum & 3. & 3 & 0.37 \\
\hline 199501Gomphonema olivaceoides & 3. & 44. & 5.49 \\
\hline 199501 Gomphonema olivaceum & 3. & 7 & 0.87 \\
\hline 199501Gomphonema parvulum & 1. & 2 & 0.25 \\
\hline 199501 Hannaea arcus & 3 & 227 & 28.30 \\
\hline 199501Hantzschia amphioxys & 2 & 0 & 0.00 \\
\hline 199501 Meridion circulare & 3 & 1. & 0.12 \\
\hline 199501 Navicula capitatoradiata & 2 & 1. & 0.12 \\
\hline 199501 Navicula cryptocephala & 3 & 4. & 0.50 \\
\hline 199501 Navicula cryptotenella & 2 & 12 & 1.50 \\
\hline 199501 Navicula gregaria & 2 & 0 & 0.00 \\
\hline 199501 Navicula menisculus & 2 & 2 & 0.25 \\
\hline 199501 Navicula minima & 1. & 6 & 0.75 \\
\hline 199501 Navicula minuscula & 1. & 6 & 0.75 \\
\hline 199501 Navicula novaesiberica & 2 & 2 & 0.25 \\
\hline 199501 Navicula pupula & 2 & 0 & 0.00 \\
\hline 199501 Navicula reichardtiana & 2 & 2 & 0.25 \\
\hline 199501 Navicula tripunctata & 3. & 1 & 0.12 \\
\hline 199501 Nitzschia bacillum & 3. & 0 & 0.00 \\
\hline 199501 Nitzschia dissipata & 3 & 14 & 1.75 \\
\hline 199501 Nitzschia fonticola & 3 & 4. & 0.50 \\
\hline 199501 Nitzschia hantzschiana & 3 & 2 & 0.25 \\
\hline 199501 Nitzschia inconspicua & 2 & 18 & 2.24 \\
\hline 199501 Nitzschia linearis & 2 & 1. & 0.12 \\
\hline 199501 Nitzschia palea & 1. & 4 & 0.50 \\
\hline 199501 Nitzschia paleacea & 2 & 61 & 7.61 \\
\hline 199501 Nitzschia perminuta & 3 & 15 & 1.87 \\
\hline 199501 Nitzschia pura & 2 & 5 & 0.62 \\
\hline 199501 Reimeria sinuata & 3 & 20 & 2.49 \\
\hline 199501Rhoicosphenia curvata & 3 & 25 & 3.12 \\
\hline 199501 Synedra rumpens & 2. & 2 & 0.25 \\
\hline 199501 Synedra ulna & 2 & 2 & 0.25 \\
\hline
\end{tabular}




\begin{tabular}{|c|c|c|c|c|}
\hline Sample & Genus/Species Nariety & Pollution Tolerance Class & Count & Percent \\
\hline \multicolumn{2}{|c|}{ 199401 Achnanthes bioretii } & 3 & 4 & 0.50 \\
\hline \multicolumn{2}{|c|}{ 199401 Achnanthes lanceolata } & 2 & 2 & 0.25 \\
\hline \multicolumn{2}{|c|}{199401 Achnanthes minutissima } & 3 & 107 & 13.38 \\
\hline \multicolumn{2}{|c|}{199401 Amphora inariensis } & 3 & 2 & 0.25 \\
\hline \multicolumn{2}{|c|}{ 199401 Amphora pediculus } & 3 & 2 & 0.25 \\
\hline \multicolumn{2}{|c|}{199401 Cocconeis placentula } & 3 & 9 & 1.13 \\
\hline \multicolumn{2}{|c|}{199401 Cymbella affinis } & 3 & 3 & 0.38 \\
\hline \multicolumn{2}{|c|}{199401 Cymbella cymbiformis } & 3 & 2 & 0.25 \\
\hline \multicolumn{2}{|c|}{199401 Cymbella minuta } & 2 & 2 & 0.25 \\
\hline \multicolumn{2}{|c|}{199401 Cymbella silesiaca } & 2 & 2 & 0.25 \\
\hline \multicolumn{2}{|c|}{199401 Diatoma hiemale } & 3 & 2 & 0.25 \\
\hline \multicolumn{2}{|c|}{199401 Diatoma mesodon } & 3 & 8 & 1.00 \\
\hline \multicolumn{2}{|c|}{ 199401 Fragilaria leptostauron } & 3 & 2 & 0.25 \\
\hline \multicolumn{2}{|c|}{199401 Gomphonema angustatum } & 2 & 88 & 11.00 \\
\hline \multicolumn{2}{|c|}{199401 Gomphonema kobayasii } & 3 & 6 & 0.75 \\
\hline \multicolumn{2}{|c|}{199401 Gomphonema minutum } & 3 & 2 & 0.25 \\
\hline \multicolumn{2}{|c|}{199401 Gomphonema olivaceoides } & 3 & 498 & 62.25 \\
\hline \multicolumn{2}{|c|}{199401 Gomphonema parvulum } & 1 & 7. & 0.88 \\
\hline \multicolumn{2}{|c|}{199401 Gomphonema subtile } & 3 & 4 & 0.50 \\
\hline \multicolumn{2}{|c|}{199401 Hannaea arcus } & 3 & 26 & 3.25 \\
\hline \multicolumn{2}{|c|}{199401 Meridion circulare } & 3 & 4 & 0.50 \\
\hline \multicolumn{2}{|c|}{199401 Navicula cryptotenella } & 2 & 4 & 0.50 \\
\hline \multicolumn{2}{|c|}{199401 Navicula radiosa } & 3 & 2 & 0.25 \\
\hline \multicolumn{2}{|c|}{199401 Navicula sp. } & 2 & 2 & 0.25 \\
\hline \multicolumn{2}{|c|}{ 199401 Reimeria sinuata } & 3 & 10 & 1.25 \\
\hline
\end{tabular}




\begin{tabular}{|c|c|c|c|}
\hline Genus/SpeciesNariety & Pollution Tolerance Class & Count & Percent \\
\hline 199601 Achnanthes Ianceolata & 2 & 25 & 3.00 \\
\hline 199601 Achnanthes lapidosa & 3 & 0 & 0.00 \\
\hline 199601 Achnanthes minutissima & 3 & 48 & 5.76 \\
\hline 199601 Amphora inariensis & 3 & 0 & 0.00 \\
\hline 199601 Aulacoseira crenulata & 3 & 1. & 0.12 \\
\hline 199601 Cocconeis pediculus & 3 & 1 & 0.12 \\
\hline 199601 Cocconeis placentula & 3 & 15 & 1.80 \\
\hline 199601 Cymbella silesiaca & 2 & 11 & 1.32 \\
\hline 199601 Diatoma mesodon & 3 & 2 & 0.24 \\
\hline 199601 Diploneis oblongella & 3 & 1 & 0.12 \\
\hline 199601 Eunotia sp. & 3 & 11 & 1.32 \\
\hline 199601 Fragilaria capucina & 2 & 18 & 2.16 \\
\hline 199601 Fragilaria construens & 3 & 20 & 2.40 \\
\hline 199601 Fragilaria Iapponica & 3 & 1 & 0.12 \\
\hline 199601 Fragilaria leptostauron & 3 & 1 & 0.12 \\
\hline 199601 Fragilaria pinnata & 3. & 0 & 0.00 \\
\hline 199601 Fragilaria vaucheriae & 2 & 101 & 12.11 \\
\hline 199601 Frustulia vulgaris & 2 & 0 & 0.00 \\
\hline 199601 Gomphoneis eriense & 3 & 7 & 0.84 \\
\hline 199601 Gomphoneis minuta & 3 & 2 & 0.24 \\
\hline 199601 Gomphonema angustatum & 2 & 2 & 0.24 \\
\hline 199601 Gomphonema minutiforme & 3 & 6 & 0.72 \\
\hline 199601 Gomphonema minutum & 3 & 4 & 0.48 \\
\hline 199601 Gomphonema olivaceoides & 3 & 20 & 2.40 \\
\hline 199601 Gomphonema olivaceum & 3. & 0 & 0.00 \\
\hline 199601 Gomphonema parvulum & 1 & 3 & 0.36 \\
\hline 199601 Hannaea arcus & 3. & 15 & 1.80 \\
\hline 199601 Melosira varians & 2 & 17 & 2.04 \\
\hline 199601 Meridion circulare & 3 & 1 & 0.12 \\
\hline 199601 Navicula acceptata & 2 & 4 & 0.48 \\
\hline 199601 Navicula capitatoradiata & 2 & 12 & 1.44 \\
\hline 199601 Navicula contenta & 2 & 5 & 0.60 \\
\hline 199601 Navicula cryptocephala & 3 & 2 & 0.24 \\
\hline 199601 Navicula cryptotenella & 2 & 61 & 7.31 \\
\hline 199601 Navicula exigua & 2 & 2 & 0.24 \\
\hline 199601 Navicula exilis & 2 & 1 & 0.12 \\
\hline 199601 Navicula gregaria & 2 & 1 & 0.12 \\
\hline 199601 Navicula Ianceolata & 2 & 4 & 0.48 \\
\hline 199601 Navicula libonensis & 2. & 0 & 0.00 \\
\hline 199601 Navicula menisculus & 2 & 5 & 0.60 \\
\hline 199601 Navicula minima & 1 & 15 & 1.80 \\
\hline 199601 Navicula minuscula & 1 & 2 & 0.24 \\
\hline 199601 Navicula novaesiberica & 2 & 0 & 0.00 \\
\hline 199601 Navicula sp. & 2 & 3 & 0.36 \\
\hline 199601 Navicula tripunctata & 3 & 12. & 1.44 \\
\hline 199601 Nitzschia archibaldii & 2 & 4 & 0.48 \\
\hline 199601 Nitzschia bacillum & 3 & 1 & 0.12 \\
\hline
\end{tabular}




\begin{tabular}{|c|c|c|c|c|}
\hline Sample & Genus/SpeciesNariety & Pollution Tolerance Class & Count & Percent \\
\hline \multicolumn{2}{|c|}{199601 Nitzschia dissipata } & 3 & 175 & 20.98 \\
\hline \multicolumn{2}{|c|}{199601 Nitzschia fonticola } & 3 & 7 & 0.84 \\
\hline \multicolumn{2}{|c|}{ 199601 Nitzschia frustulum } & 2 & 4 & 0.48 \\
\hline \multicolumn{2}{|c|}{199601 Nitzschia gracilis } & 2 & 0 & 0.00 \\
\hline \multicolumn{2}{|c|}{199601 Nitzschia heufleriana } & 3 & 0 & 0.00 \\
\hline \multicolumn{2}{|c|}{199601 Nitzschia inconspicua } & 2 & 27 & 3.24 \\
\hline \multicolumn{2}{|c|}{199601 Nitzschia linearis } & 2 & 26 & 3.12 \\
\hline \multicolumn{2}{|c|}{199601 Nitzschia palea } & 1. & 22 & 2.64 \\
\hline \multicolumn{2}{|c|}{199601 Nitzschia paleacea } & 2 & 43 & 5.16 \\
\hline \multicolumn{2}{|c|}{199601 Nitzschia perminuta } & 3 & 5 & 0.60 \\
\hline \multicolumn{2}{|c|}{199601 Pinnularia borealis } & 2 & 0 & 0.00 \\
\hline \multicolumn{2}{|c|}{199601 Reimeria sinuata } & 3 & 5 & 0.60 \\
\hline \multicolumn{2}{|c|}{ 199601 Rhoicosphenia curvata } & 3 & 33 & 3.96 \\
\hline \multicolumn{2}{|c|}{ 199601 Rhopalodia gibba } & 2 & 0 & 0.00 \\
\hline \multicolumn{2}{|c|}{199601 Surirella minuta } & 2 & 10 & 1.20 \\
\hline \multicolumn{2}{|c|}{199601 Synedra parasitica } & 2 & 2 & 0.24 \\
\hline \multicolumn{2}{|c|}{199601 Synedra rumpens } & 2 & 4 & 0.48 \\
\hline \multicolumn{2}{|c|}{199601 Synedra ulna } & 2 & 4 & 0.48 \\
\hline
\end{tabular}


1

0 


\begin{tabular}{|c|c|c|c|}
\hline Genus/Species/Variety & Pollution Tolerance Class & Count & Percent \\
\hline 199701 Achnanthes lanceolata & $\begin{array}{r}2 \\
\end{array}$ & 32 & 3.78 \\
\hline 199701 Achnanthes lapidosa & 3 & 2 & 0.24 \\
\hline 199701 Achnanthes minutissima & 3 & 53 & 6.26 \\
\hline 199701 Amphora pediculus & 3 & 5 & 0.59 \\
\hline 199701 Aulacoseira italica & 3 & 5 & 0.59 \\
\hline 199701 Cocconeis pediculus & 3 & 33 & 3.90 \\
\hline 199701 Cocconeis placentula & 3 & 15 & 1.77 \\
\hline 199701 Cymbella silesiaca & 2. & 9 & 1.06 \\
\hline 199701 Diatoma hiemale & 3 & 3 & 0.35 \\
\hline 199701 Diatoma mesodon & 3 & 3 & 0.35 \\
\hline 199701 Fragilaria capucina & 2 & 22 & 2.60 \\
\hline 199701 Fragilaria construens & 3 & 19 & 2.25 \\
\hline 199701 Fragilaria Iapponica & 3 & 0 & 0.00 \\
\hline 199701 Fragilaria Ieptostauron & 3 & 1 & 0.12 \\
\hline 199701 Fragilaria pinnata & 3 & 2 & 0.24 \\
\hline 199701 Fragilaria vaucheriae & 2 & 91 & 10.76 \\
\hline 199701 Frustulia vulgaris & 2 & 0 & 0.00 \\
\hline 199701 Gomphoneis eriense & 3 & 10 & 1.18 \\
\hline 199701 Gomphoneis minuta & 3 & 2 & 0.24 \\
\hline 199701 Gomphonema angustatum & 2 & 3 & 0.35 \\
\hline 199701 Gomphonema kobayasii & 3 & 12 & 1.42 \\
\hline 199701 Gomphonema minutiforme & 3 & 2 & 0.24 \\
\hline 199701 Gomphonema minutum & 3 & 4 & 0.47 \\
\hline 199701 Gomphonema olivaceoides & 3 & 23 & 2.72 \\
\hline 199701 Gomphonema parvulum & 1 & 3 & 0.35 \\
\hline 199701 Gomphonema pumilum & 3 & 4 & 0.47 \\
\hline 199701 Hannaea arcus & 3 & 6 & 0.71 \\
\hline 199701 Melosira varians & 2 & 25 & 2.96 \\
\hline 199701 Meridion circulare & 3 & 1 & 0.12 \\
\hline 199701 Navicula accomoda & 1 & 0 & 0.00 \\
\hline 199701 Navicula capitatoradiata & 2 & 20 & 2.36 \\
\hline 199701 Navicula caterva & 2 & 2 & 0.24 \\
\hline 199701 Navicula cincta & 1 & 0 & 0.00 \\
\hline 199701 Navicula cryptocephala & 3. & 1 & 0.12 \\
\hline 199701 Navicula cryptotenella & 2 & 55 & 6.50 \\
\hline 199701 Navicula Ianceolata & 2 & 3 & 0.35 \\
\hline 199701 Navicula libonensis & 2 & 1 & 0.12 \\
\hline 199701 Navicula menisculus & 2 & 8 & 0.95 \\
\hline 199701 Navicula minima & 1 & 8 & 0.95 \\
\hline 199701 Navicula minuscula & 1 & 5 & 0.59 \\
\hline 199701 Navicula mutica & 2 & 2. & 0.24 \\
\hline 199701 Navicula novaesiberica & 2 & 2 & 0.24 \\
\hline 199701 Navicula pelliculosa & 1 & 6 & 0.71 \\
\hline 199701 Navicula reichardtiana & 2 & 2 & 0.24 \\
\hline 199701 Navicula sp. & 2 & 0 & 0.00 \\
\hline 199701 Navicula tripunctata & 3 & 13 & 1.54 \\
\hline 199701 Navicula veneta & 1 & 1 & 0.12 \\
\hline
\end{tabular}




\begin{tabular}{|c|c|c|c|}
\hline Genus/SpeciesNariety & Pollution Tolerance Class & Count & Percent \\
\hline 199701 Nitzschia alpina & 3 & 3 & 0.35 \\
\hline 199701 Nitzschia archibaldii & 2 & 1 & 0.12 \\
\hline 199701 Nitzschia dissipata & 3 & 130 & 15.37 \\
\hline 199701 Nitzschia fonticola & 3 & 7 & 0.83 \\
\hline 199701 Nitzschia heufleriana & 3 & 4 & 0.47 \\
\hline 199701 Nitzschia incognita & 2 & 0 & 0.00 \\
\hline 199701 Nitzschia inconspicua & 2 & 35 & 4.14 \\
\hline 199701 Nitzschia lacuum & 3 & 2 & 0.24 \\
\hline 199701 Nitzschia linearis & 2 & 42 & 4.96 \\
\hline 199701 Nitzschia palea & 1 & 28 & 3.31 \\
\hline 199701 Nitzschia paleacea & 2 & 16 & 1.89 \\
\hline 199701 Nitzschia perminuta & 3 & 1 & 0.12 \\
\hline 199701 Pinnuiaria sp. & 3 & 1 & 0.12 \\
\hline 199701 Reimeria sinuata & 3 & 12 & 1.42 \\
\hline 199701 Rhoicosphenia curvata & 3 & 24 & 2.84 \\
\hline 199701 Rhopalodia gibba & 2 & 0 & 0.00 \\
\hline 199701 Simonsenia delognei & 2 & 1. & 0.12 \\
\hline 199701 Surirella angusta & 1 & 2 & 0.24 \\
\hline 199701 Surirella linearis & 3 & 1 & 0.12 \\
\hline 199701 Surirella minuta & 2 & 14 & 1.65 \\
\hline 199701 Synedra rumpens & 2 & 2 & 0.24 \\
\hline 199701 Synedra uina & 2 & 1 & 0.12 \\
\hline
\end{tabular}


<smiles>C=C=C=C=C=C</smiles> 
